\title{
Augmentation mammoplasty: how it is done, recovery and frequent questions.
}

Emilio Valls (1)

\section{ARTIGO DE REVISÃO}

\begin{abstract}
Cosmetic surgery to insert silicone prosthesis may be indicated when the woman has very small breasts, is afraid of not being able to breastfeed, has noticed a reduction in their size or has lost a lot of weight. But it can also be indicated when a woman has breasts with different sizes or needed to remove the breast or part of the breast due to cancer. This surgery can be done from the age of 15 with parental permission, and is performed under general anesthesia, taking about 45 minutes, and can be with a short hospital stay of 1 or 2 days, or even in an outpatient setting, when he is discharged on the same day.
\end{abstract}

Keywords: Mammoplasty, Silicone, Silicone implants. 


\section{Mamoplastia de aumento: como é feita, recuperação e dúvidas frequentes.}

\section{Resumo}

A cirurgia estética para colocar prótese de silicone pode estar indicada quando a mulher tem os seios muito pequenos, tem medo de não conseguir amamentar, notou alguma redução no seu tamanho ou perdeu muito peso. Mas também pode ser indicada quando a mulher apresenta mamas com tamanhos diferentes ou precisou retirar a mama ou parte da mama devido ao câncer. Esta cirurgia pode ser feita a partir dos 15 anos com autorização dos pais, e é feita com anestesia geral, demorando cerca de 45 minutos, e pode ser com com internamento curto de 1 ou 2 dias, ou mesmo em regime de ambulatório, quando se tem alta no próprio dia.

Palavras-chave: Mamoplastia, Silicone, Implantes de silicone

Instituição afiliada: 1- Plastic Surgeon at the Women's Disease Reference Center in George Town George Town - English Guiana.

Dados da publicação: Artigo recebido em 03 de junho, revisado em 25 de junho, aceito para publicação em 10 de julho e publicado em 31 de agosto.

DOI: https://doi.org/10.36557/2674-8169.2021v3n8p15-21

Emilio Valls vallsmed33@gmail.com

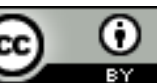

This work is licensed under a Creative Commons Attribution 4.0 International

License. 


\section{INTRODUÇÃO}

Cosmetic surgery to insert silicone prosthesis may be indicated when the woman has very small breasts, is afraid of not being able to breastfeed, has noticed a reduction in their size or has lost a lot of weight. But it can also be indicated when a woman has breasts with different sizes or needed to remove the breast or part of the breast due to cancer.

This surgery can be done from the age of 15 with parental permission, and is performed under general anesthesia, taking about 45 minutes, and can be with a short hospital stay of 1 or 2 days, or even in an outpatient setting, when he is discharged on the same day.

The most common complications are chest pain, decreased sensation and rejection of the silicone implant, called capsular contracture, which can occur in some women. Other rarer complications are rupture due to a strong blow, hematoma and infection.

After deciding to put silicone in the breasts, the woman should look for a good plastic surgeon to safely perform the procedure, thus reducing the risks of surgery.

\section{How is breast augmentation performed}

In breast augmentation or plastic surgery with silicone implants, a small cut is made in both breasts around the areola, in the lower part of the breast or even in the armpit through which the silicone is introduced, which increases the volume of the breast.

After the cut, the doctor stitches and places 2 drains through which the fluids that accumulate in the body leave to avoid complications such as hematoma or seroma.

\section{How to choose a silicone implant}

Silicone implants must be chosen between the surgeon and the woman, and it is important to decide:

Prosthesis shape: it can be in a drop shape, more natural, or in a round shape, 
more appropriate for women who already have a breast. This round shape is safer because the teardrop shape is more likely to rotate inside the breast, making it crooked. In the case of the round prosthesis, a natural shape can also be achieved by injecting fat around it, called lipofilling.

Prosthesis profile: it can have a high, low or medium profile, the higher the profile, the more upright the breast is, but also a more artificial result;

Prosthesis size: varies according to the height and physical structure of the woman, it is common to use prostheses with $300 \mathrm{ml}$. However, prostheses with more than $400 \mathrm{ml}$ should only be placed in tall women, with a wider chest and hips.

Place of placement of the prosthesis: silicone can be placed above or below the pectoral muscle. It is best to put it over the muscle when you have enough skin and fat for it to look natural, while it is recommended to put it under the muscle when you have virtually no breasts or are very thin.

In addition, the prosthesis can be silicone or saline and can have a smooth or rough texture, and it is recommended to use cohesive and textured silicone, which means that if it breaks it does not disintegrate and reduces the risk of infection, with lower chances of developing rejection, infection, and silicone leaving the breast. Nowadays, completely smooth or over-textured dentures seem to be the cause of a greater number of contractures or rejection.

\section{How to prepare for surgery}

- Before performing the surgery for silicone placement, it is recommended:

- Get blood tests done in the lab to confirm it is safe to perform the surgery;

- ECG From the age of 40 , it is recommended to carry out an electrocardiogram to check that the heart is healthy;

- Take prophylactic antibiotics such as amoxicillin the day before surgery and adjust the doses of current medications as indicated by the doctor;

- Stop smoking at least 15 days before surgery;

Avoid taking some medications such as aspirin, anti-inflammatory drugs and natural medications in the previous 15 days, as they may increase bleeding, as indicated by the doctor. 
On the day of surgery, you should fast for about 8 hours and during hospitalization, the surgeon will be able to trace the breasts with a pen to delineate the cut sites for the surgery, in addition to deciding the size of the silicone implants.

\section{How is recovery from surgery}

The total recovery time from the augmentation mammoplasty is about 1 month and the pain and discomfort is slowly decreasing, and 3 weeks after the surgery it is usually possible to work, walk and train without exercising with the arms.

During the post-operative period, you may have to have 2 drains for about 2 days, which are containers where excess blood accumulated in the chest leaves to avoid complications. Some surgeons who perform infiltration with local tumescent anesthesia may not need drains. To relieve pain, analgesics and antibiotics are administered.

In addition, it is necessary to maintain some precautions, such as:

Always sleep on your stomach during the first month, avoiding sleeping on your side or stomach;

Wear an elastic bandage or a comfortable elastic bra to support the prosthesis for at least 3 weeks, not even taking it off to sleep;

Avoid doing too many movements with your arms, such as driving or exercising intensely, for 20 days;

Only take a full bath normally after 1 week or when the doctor indicates and do not wet or change the dressings at home;

Remove stitches and dressings for 3 days to a week at the medical clinic.

The first results of the surgery are noticed right after the surgery, however, the definitive result should be seen within 4 to 8 weeks, with invisible scars.

\section{how is the scar}

The scars vary with the places where the cuts were made in the skin, with small scars being frequent in the armpit, in the lower part of the breast or in the areola, however, these are usually very discreet. 


\section{Possible complications}

The main complications of breast lifts are chest pain, hard breasts, a feeling of heaviness that causes a curved back, and decreased sensitivity in the breast.

There may also be hematoma, which causes swelling and redness of the breast and, in more severe cases, hardening around the prosthesis and rejection or rupture of the prosthesis can occur, which leads to the need to remove the silicone. In very rare cases there may also be infection of the prosthesis.

\section{Frequently Asked Questions About Mammoplasty}

Some frequently asked questions are:

\section{Can I put silicone before getting pregnant?}

Mammoplasty can be done before becoming pregnant, but it is common for the breast to become smaller and sagging after breastfeeding, and it may be necessary to undergo a new surgery to repair this problem and, therefore, women often choose to put silicone after breastfeeding.

2. Do I need to change the silicone after 10 years?

In most cases, silicone breast implants do not need to be changed, however it is essential to go to the doctor and do tests such as MRI at least every 4 years to check that the implants have no changes.

However, in some cases the dentures may need to be changed, mainly occurring 10 to 20 years after their placement.

\section{Does silicone cause cancer?}

Studies carried out around the world indicate that the use of silicone does not increase the chances of developing breast cancer. However, you should inform your physician that you have a silicone implant when performing a mammogram.

There is a very rare breast cancer called giant cell lymphoma of the breast that may have to do with the use of silicone implants, but due to the limited number of cases reported worldwide of this disease it is difficult to know for sure if this relationship exists.

In most cases, performing breast augmentation and breast lift surgery brings better results, especially when the woman has a sagging breast.

\section{THE AUTHORS DECLARE NO CONFLICTS OF INTEREST.}




\section{REFERÊNCIAS}

1- MINISTÉRIO DA SAÚDE. Diretrizes clínicas para o cuidado ao paciente com doença renal crônica - DCR no sistema único de saúde. 2014. Disponível em: <https://bvsms.saude.gov.br/bvs/publicacoes/diretrizes_clinicas_cuidado_paciente_ren al.pdf>. Acesso em 19 Mar 2021

2- EBSERH. Insuficiência Renal Aguda.

Disponível em: <http://www2.ebserh.gov.br/documents/214336/1108363/Cap\%C3\%ADtulo-37Insufici\%C3\%AAncia-Renal-Aguda.pdf/48bb79d4-7216-4da2-82b0-5259bb9db1ea>. Acesso em 19 Mar 2021

3- Tua Saúde. Disponível em: https://www.tuasaude.com/insuficiencia-renal/ 